\title{
PEMBELAJARAN TEMATIK TERPADU DENGAN MENGGUNAKAN MODEL QUANTUM TEACHING
}

\author{
Nadya Yolanda ${ }^{1,}$ Reinita $^{2}$ \\ Universitas Negeri Padang ${ }^{1,2}$ \\ nadia280818@gmail.com ${ }^{1}$
}

\begin{abstract}
ABSTRAK
Penelitian ini bertujuan untuk mendeskripsikan peningkatan proses pembelajaran tematik terpadu dengan menggunakan model Quantum Teaching di kelas V SD N 16 Koto Baru Solok. Jenis penelitian yang digunakan adalah Penelitian Tindakan Kelas (PTK). Subjek pada penelitian adalah guru dan siswa sebanyak 22 orang. Tempat penelitian di SD N 16 Koto Baru Solok. Hasil penelitian menunjukkan adanya peningkatan pada: a) RPP siklus I dengan rata-rata ialah $80,05 \%$ dan siklus II $97,22 \%$, b) Pelaksanaan pada aspek guru siklus Idengan rata-rata ialah $77,77 \%$ dan siklus II 94,44\%, sedangkan pelaksanaan pada aspek siswa siklus I denga rata-rata ialah $79,1 \%$ dan siklus II 94,44\% (sangat baik), d) Penilaian hasil belajar siswa pada siklus I dengan rata-rata ialah 72,9 dan siklus II 94. Simpulan, bahwa penerapan model Quantum Teaching menunjukkan peningkatan hasil dan proses pembelajaran siswa pada pembelajaran tematik terpadu.
\end{abstract}

Kata Kunci: Quantum Teaching; Tematik Terpadu

\begin{abstract}
This study aims to describe the improvement of integrated thematic learning processes using the Quantum Teaching model in class V SD N 16 Koto Baru Solok. This type of research is Classroom Action Research (CAR). Subjects in the study were 22 teachers and students. Research site at SD N 16 Koto Baru Solok. The results showed an increase in: a) RPP cycle I with an average of $80.05 \%$ and cycle II $97.22 \%, b)$ Implementation of the aspects of the teacher Idengan cycle on average was $77.77 \%$ and cycle II 94, 44\%, while the implementation of aspects of the first cycle students with an average of $79.1 \%$ and the second cycle $94.44 \%$ (very good), d) Assessment of student learning outcomes in the first cycle with an average of 72.9 and the cycle II 94. Conclusion, that the application of the Quantum Teaching model shows an increase in student learning outcomes and processes in integrated thematic learning.
\end{abstract}

Keyword : Quantum Teaching; integrated thematic 


\section{PENDAHULUAN}

Kurikulum merupakan suatu perangkat yang dijadikan pedoman dalam mengembangkan suatu proses pembelajaran yang berhubungan dengan kegiatan siswa untuk mencapai tujuan pendidikan dan pembelajaran. Pada tingkat pendidikan sekolah dasar (SD) tematik terpadu bercirikan mata pelajaran yang diintegrasikan ke dalam tema serta menyatukan beberapa materi ke dalam satu mata pelajaran menghubungkan mata pelajaran satu dengan mata pelajaran lainnya. Menurut Poerwadarminta dalam Majid (2014) "Tema adalah pokok pikiran atau gagasan pokok yang menjadi pokok pembicaraan".

Tematik terpadu pembelajarannya lebih menekankan pada proses, sehingga siswa lebih aktif, kritis, dan juga terlibat dalam proses pembelajaran. Tujuan dari kurikulum ini untuk menciptakan pembelajaran yang bermakna. Hal ini dipertegas oleh Rusman (2015) yaitu "pembelajaran tematik memfokuskan agar siswa dapat terlibat dalam proses pembelajaran sehingga siswa menjadi lebih aktif dan memperoleh pengalaman secara langsung". Pembelajaran tematik terpadu lebih melibatkan siswa dalam proses belajar melalui pengalaman langsung, siswa dapat lebih mudah memahami konsep-konsep materi dan menghubungkan dengan kehidupan sehari-hari. Tema menunjang beberapa mata pelajaran dan materi yang disajikan dalam pembelajaran sebisa mungkin lebih dihubungkan dengan kehidupan sahari-hari untuk menciptakan siswa yang lebih aktif dan kritis.

Berdasarkan observasi yang dilakukan peneliti di SD N 16 Koto Baru Solok pada tanggal 19-20 Juli 2018, dapat dilihat bahwa guru kurang mengembangkan model pembelajaran yang bervariasi.Dalam kegiatan pembelajaran guru kurang memotivasi siswa dalam memulai pembelajaran, kurang menghadirkan interaksi-interaksi berbeda dalam proses belajar, kurang memberi kesempatan pada siswa untuk menyampaikan pendapatnya, kurangmelatih siswa untuk mengaitkan materi dengan lingkungan, kurang melibatkan siswa secara aktif dalam proses pembelajaran.

Kurang mampunya guru dalam proses pembelajaran mengakibatkan rendahnya pemahaman dan penguasaan materi pada siswa. Hal ini terlihat dari siswa kurang bersemangat memulai pembelajaran, kurang antusias dalam membahas materi karena interaksi yang monoton, kurangnya kepercayaan diri mengemukakan ide, sulit untuk mengembangkan kemampuan berfikirnya sesuai dengan lingkungansekitar, siswa terlihat lebih pasif karena kurang memahami materi.

Dari beberapa fenomena yang ditemukan ini perlu dicarikan solusinya. Untuk meningkatkan proses pembelajaran peneliti menggunakan model Quantum Teaching pada pembelajaran tematik terpadu tema 4 subtema 2 yang terdapat muatan pelajaran PKn, IPS, dan B.Indonesia. Pembelajaran PKn secara umum menurut Reinita (2012) yaitu "pembelajaran tentang nilai-nilai yang lebih ditekankan pada penanaman nilai-nilai, moral sesuai budaya bangsa Indonesia tanpa mengenyampingkan pengajaran konsep atau pengetahuan moral pada siswa". Pembelajaran IPS secara umum menurut Reinita (2017) menyatakan kembali yaitu "membentuk siswa yang dapat memahami kehidupannya sebagai makhluk sosial dan melestarikan nilai-nilai karakter yang ada dalam masyarakat". 
Sedangkan pembelajaran B.Indonesia menurut Khair (2018:89) yaitu "membelajarkan peserta didik tentang keterampilan berbahasa Indonesia yang baik dan benar".

Dengan adanya tiga muatan pembelajaran ini peneliti menggunakan model Quantum Teaching dimana model ini dapat membuat siswa menjadi lebih antusias, bersemangat, mampu berfikir lebih kritis, meningkatkan kepercayaan diri merekaserta mengajarkan untuk bertukar fikiran secara kelompok sesuai lingkungan sekitar dan menghadirkan proses pembelajaran terutama pada pembelajaran PKn, IPS, dan B.indonesia menjadi tidak monoton sehingga memudahkan siswa menerima materi pembelajaran. Model ini cocok digunakan untuk meningkatkan proses pembelajaran siswa sehingga hasil belajar juga dapat meningkat.

Hakim (2017) dalam hasil penelitiannya menjelaskan bahwa Quantum adalah interaksi yang mengubah energi menjadi cahaya. Jadi Quantum Teaching mencipatakan lingkungan yang efektif, dengan cara menggunakan unsur pada siswa dan lingkungan belajarnya melalui interaksi yang terjadi di dalam kelas.

Tujuan dari penelitian ini adalah untuk mendeskripsikan peningkatan proses pembelajaran tematik terpadu tema 4 subtema 2 dengan menggunakan model Quantum Teaching di kelas V SD N 16 Koto Baru Solok.

\section{METODE PENELITIAN}

Jenis penelitian yang digunakan pada penelitian ini adalah penelitian tindakan kelas. Penelitian ini dilaksanakan pada semester I tahun ajaran 2018/2019 di kelas V SD N 16 Koto Baru Solok. Penelitian ini dilakukan sebanyak dua siklus. Siklus I terdiri dari 2 pertemuan dan Siklus II . Siklus I pertemuan 1 dilaksanakan pada hari Senin, 05 November 2018. Siklus I pertemuan 2 dilaksanakan pada hari Rabu, 14 November 2018 dan Siklus II dilaksanakan pada hari Sabtu, 17 November 2018. Sumber data penelitian ini adalah proses kegiatan pembelajaran tematik terpadu dengan menggunakan model Quantum Teachingdi kelas V SD N 16 Koto Baru Solok yang meliputi perencanaan, pelaksanaan, dan penilaian proses pembelajaran. Data diperoleh dari subjek yang diteliti yaitu guru (praktisi) dan peserta didik kelas V SD N 16 Koto Baru Solok. Data penelitian ini dikumpulkan dengan menggunakan teknik observasi dan tes.

Agar tujuan penelitian ini tercapai digunakan instrumen penelitian yaitu lembaran observasi dan lembar tes. Aspek yang diamati adalah RPP, pelaksanaan pembelajaran pada aspek guru dan aspek peserta didik. Lembar tes digunakan untuk memperkuat data observasi terhadap penilaian proses dan hasil belajar. Data yang diperoleh dalam penelitian dianalisis dengan menggunakan model analisis kualitatif dan kuantitatif. Model analisis kualitatif menurut Miles dan Huberham (dalam Reinita: 2012) yaitu "Analisis dimulai dengan menelaah data yang telah terkumpul, data tersebut direduksi meliputi pengkategorian, diikuti penyajian data dan menyimpulkan hasil penelitian". Sedangkan model analisis kuantitatif terhadap proses belajar siswa dikemukakan permendibud No 104 tahun 2014 menggunakan rumus perhitungan dan penskoran untuk pengetahuan dan keterampilan, yaitu: 
Nilai $=$ Jumlah skor siswa $\mathrm{x} 100$

Jumlah skor maksimal

Tabel 1

Kriteria Keberhasilan Perhitungan Aspek Pengetahuan dan Keterampilan

\begin{tabular}{|c|c|c|c|}
\hline \multicolumn{2}{|c|}{$\begin{array}{l}\text { Konversi } \\
\text { nilai akhir }\end{array}$} & \multirow[t]{3}{*}{$\begin{array}{c}\text { Predikat (pengetahuan dan } \\
\text { keterampilan) }\end{array}$} & \multirow[t]{3}{*}{$\begin{array}{c}\text { Klasifikasi sikap dan } \\
\text { esktrakulikuler }\end{array}$} \\
\hline Skala & Skala & & \\
\hline $0-100$ & $1-4$ & & \\
\hline $86-100$ & 4 & A & SB \\
\hline $81-85$ & 3.66 & A- & \\
\hline $76-80$ & 3.33 & $\mathrm{~B}+$ & B \\
\hline $71-75$ & 3.00 & $B$ & \\
\hline $66-70$ & 2.66 & B- & \\
\hline $61-65$ & 2.33 & $\mathrm{C}+$ & $\mathrm{C}$ \\
\hline $56-60$ & 2 & $\mathrm{C}$ & \\
\hline $51-55$ & 1.66 & C- & \\
\hline $46-50$ & 1.33 & $\mathrm{D}+$ & $\mathrm{K}$ \\
\hline $0-45$ & 1 & $\mathrm{D}$ & \\
\hline
\end{tabular}

Sedangkan untuk menghitung persentase hasil pengamatan praktik pembelajaran dalam kemendikbud (2016) sebagai berikut:

Tabel 2

Kriteria taraf keberhasilan Pengamatan Praktik Pembelajaran

\begin{tabular}{cc}
\hline Rentang Predikat & Nilai \\
\hline Amat Baik $(\mathrm{AB})$ & $90<\mathrm{A} \leq 100$ \\
\hline Baik $(\mathrm{B})$ & $80<\mathrm{B} \leq 90$ \\
\hline Cukup $(\mathrm{C})$ & $70<\mathrm{C} \leq 80$ \\
\hline Kurang $(\mathrm{K})$ & $\mathrm{D}<70$ \\
\hline
\end{tabular}

\section{HASIL PENELITIAN}

\section{Siklus I}

Penelitian dilakukan dengan empat tahapan yaitu perencanaan, pelaksanaan, pengamatan, dan refleksi. Penelitian siklus I dilakukan sebanyak 2 kali pertemuan pada hari Senin, 05 November 2018. Siklus I pertemuan 2 dilaksanakan pada hari Rabu, 14 November 2018. Perencanaan pembelajaran disusun berdasarkan langkah model Quantum Teaching dengan berpedoman pada kurikulum 2013. Sebelum Rencana Pelaksanaan Pembelajaran (RPP) disusun, peneliti menganalisis kurikulum 2013, buku guru dan siswa. Pembelajaran mengacu pada kompetensi inti, standar kompetensi, dan kompetensi dasar yang ada pada kurikulum 2013 yang dituangkan kedalam indikator dan tujuan pembelajaran. Pada pertemuan I dengan tema 4, subtema 2, pembelajaran 4. Pada pertemuan II tema 4, subtema 3 , pembelajaran 3 . 
Pelaksanaan pembelajaran pada siklus 1 melalui 3 kegiatan pembelajaran yaitu dimulai dari kegiatan pendahuluan, diawali dengan guru mengucapkan salam, mengkondisikan kelas, menyiapkan perlengkapan untuk mengajar. Guru meminta siswa untuk mengambil sampah yang ada di kelas, merapikan tempat duduk, membaca do'a bersama yang dipimpin ketua kelas dan mengambil absensi.Sebelum masuk kegiatan inti, guru melakukan apersepsi mengenai tanggung jawab dan melakukan tanggung jawab, kemudian menyampaikan tujuan pembelajaran. Pada kegiatan inti, proses pembelajaran dilaksanakan sesuai dengan lagkah-langkah model Quantum Teaching.

Langkah 1 dimana guru memajang media gambar, sebagai jembatan untuk menghubungkan siswa dengan materi pelajaran sehingga siswa akan terpikat dengan perasaan ingin tahu yang dapat menumbuhkan minat siswa untuk membahas media gambar secara bersama. Langkah 2 siswa belajar mengaitkan materi dengan kehidupan sehari-hari atau lingkungan sekitar mereka di bawah bimbingan guru. Langkah 3 dimana siswa mendengarkan pemahaman kosep dasar yang di jelaskan guru setelah itu duduk berkelompok untuk bertukar pikiran mengenai satu topik. Langkah 4 siswa menampilkan hasil karyanya ke depan kelas untuk menunjukkan kepahamannya terhadap materi yang dipelajari. Langkah 5 siswa dan guru melakukan tanya jawab mengenai materi-materi yang telah dibahas secara ringkas. Langkah 6 guru memberikan penghargaan kepada siswa yang yang telah berpartisipasi baik dan aktif saat proses pembelajaran. Kegiatan penutup dimana siswa menyimpulkan pembelajaran dibawah bimbingan guru. Pada tahap ini siswa masih malu-malu sehingga guru harus menyimpulkan kembali mengakibatkan siswa terlihat pasif.

Hasil pengamatan pada siklus I yang dilakukan pada perencanaan, pelaksanaan aspek guru, aspek siswa, dan penilaian sikap, pengetahuan, dan keterampilan. Berikut ini adalah hasil pengamatan dari ketiga aspek: pada penilaian RPP dengan rata-rata $80,05 \%$. Hasil pengamatan pada aspek guru dalam kegiatan pembelajaran dengan rata-rata $77,7 \%$. Hasil pengamatan pada aspek siswa dengan rata-rata 79,1\%. Hasil pengamatan aspek sikap dengan rata-rata 65,4. Penilaian hasil belajar diperoleh dengan rata-rata 65,8 dengan predikat $\mathrm{C}+$.

Refleksi dilakukan dalam proses pengamatan yang dilakukan observer/guru kelas pada siklus I didapati pada perencanaan, pelaksanaan, dan penilaian pada pembelajaran tematik terpadu mengunakan model Quantum Teaching belum terlaksana dengan baik dimana belum mencapai kriteria keberhasilan yang diinginkan dan kriteria ketuntasan minimum yang elah ditetapkan. Dengan demikian, peningkatan proses pembelajaran tematik terpadu akan peneliti lanjutkan pada siklus II dengan lebih baik sesuai dengan rancangan rencana pelaksanaan pembelajaran dengan menggunakan model Quantum Teaching.

\section{Siklus II}

Penelitian dilakukan dengan empat tahapan yaitu perencanaan, pelaksanaan, pengamatan, dan refleksi. Penelitian siklus II dilakukan sebanyak 1 kali pertemuan pada hari Sabtu, 17 November 2018. Perencanaan pembelajaran disusun berdasarkan langkah model Quantum Teaching dengan berpedoman pada kurikulum 2013. Sebelum Rencana 
Pelaksanaan Pembelajaran (RPP) disusun, peneliti menganalisis kurikulum 2013, buku guru dan siswa. Pembelajaran mengacu pada kompetensi inti, standar kompetensi, dan kompetensi dasar yang ada pada kurikulum 2013 yang dituangkan kedalam indikator dan tujuan pembelajaran. Pada Proses pelaksanaan tindakan pada siklus II tidak jauh berbeda dengan perencanaan silus I. Pada siklus II membahas tema 4, subtema 3, pembelajaran 4.

Pelaksanaan pembelajaran pada siklus 1 melalui 3 kegiatan pembelajaran yaitu dimulai dari kegiatan pendahuluan, diawali dengan guru mengucapkan salam, mengkondisikan kelas, menyiapkan perlengkapan untuk mengajar. Guru meminta siswa untuk mengambil sampah yang ada di kelas, merapikan tempat duduk, membaca do'a bersama yang dipimpin ketua kelas dan mengambil absensi. Kemudian guru memberi motivasi kepada siswa dengan menyanyikan salah satu lagu wajib membangkitkan jiwa patriotisme. Kemudian guru melakukan apersepsi tentang akibat tidak adanya penerapan tanggung jawab dilungkungan masyarakat. Pada kegiatan inti, proses pembelajaran dilaksanakan sesuai dengan lagkah-langkah model Quantum Teaching.

Langkah 1 dimana guru memajang media gambar, sebagai jembatan untuk menghubungkan siswa dengan materi pelajaran sehingga siswa akan terpikat dengan perasaan ingin tahu yang dapat menumbuhkan minat siswa untuk membahas media gambar secara bersama. Langkah 2 siswa belajar mengaitkan materi dengan kehidupan sehari-hari atau lingkungan sekitar mereka di bawah bimbingan guru. Langkah 3 dimana siswa mendengarkan pemahaman kosep dasar yang di jelaskan guru setelah itu duduk berkelompok untuk bertukar pikiran mengenai satu topik. Langkah 4 siswa menampilkan hasil karyanya ke depan kelas untuk menunjukkan kepahamannya terhadap materi yang dipelajari. Langkah 5 siswa dan guru melakukan tanya jawab mengenai materi-materi yang telah dibahas secara ringkas. Langkah 6 guru memberikan penghargaan kepada siswa yang yang telah berpartisipasi baik dan aktif saat proses pembelajaran.

Kegiatan penutup yang dilakukan adalah guru memancing siswa untuk menyimpulkan pembelajaran. Peserta didik berebut untuk menjawab, akhirnya guru menunjuk siswa secara acak sesuai duduk siapa yang paling rapi. Kemudian menyimpulkan secara bersama untuk melihat apakah semuanya sudah benar-benar paham. Pada akhir kegiatan guru dan siswa mengucapkan rasa syukur dan diakhiri dengan membaca salam dan terimakasih.

Hasil pengamatan pada siklus II yang dilakukan pada perencanaan, pelaksanaan aspek guru, aspek siswa, dan penilaian sikap, pengetahuan, dan keterampilan. Nilai pada penilaian RPP siklus II dengan rata-rata 97,22\%. Nilai pada aspek guru dengan rata-rata $94,44 \%$, dan pada aktivitas siswa 94,44\%. Hasil pengamatan terhadap aspek sikap dengan rata-rata 89,3. Pada hasil belajar dengan rata-rata 94 dengan prediket $\mathrm{A}$.

Refleksi dilakukan setelah didapat hasil pengamatan yang dilakukan observer/guru kelas pada siklus II didapati pada perencanaan, pelaksanaan, dan penilaian pada pembelajaran tematik terpadu mengunakan model Quantum Teaching sudah mencapai kriteria keberhasilan yang diinginkan dan kriteria ketuntasan minimum yang telah ditetapkan. Dengan demikian, peningkatan proses pembelajaran tematik terpadu dengan 
menggunakan model Quantum Teaching di kelas V SD N 16 Koto Baru Solok sudah berhasil.

Hasil dari penelitian ini menunjukkan terjadi peningkatan dari tiap siklus yang dilakukan dengan menerapkan model Quantum Teaching dikeals V pada tema 4 subtema 2. Sejalan dengan yang diteliti oleh Hakim (2017) dengan hasil pada ranah kognitif bahwa terjadi peningkatan yang signifikan melalui penerapan Quantum Teaching pada mata pelajaran tematik tema 6 merawat heawan dan tumbuhan subtema 3 tumbuhan disekitarmu.

\section{PEMBAHASAN}

\section{Siklus I}

Dari hasil penelitian pelaksanaan pembelajaran peningkatan proses pembelajaran tematik terpadu, dimana terungkap bahwa guru membuat perencanaan yang dimulai dengan membuat rancangan pembelajaran dalam bentuk Rencana Pelaksnaan Pembelajaran (RPP) sesuai dengan komponen yang terdapat dalam RPP. Menurut Mansur (dalam Reinita, 2017) adalah "RPP is the design of lesson learning per unit that will be applied to teacher in learning in the classroom". Kendala yang muncul dalam perencanaan seperti, tujuan pembelajaran yang belum terlalu jelas,pemilihan materi yang belum sesuai dengan karakteristik siswa. Hal ini sesuai dengan Depdiknas (2006) "materi pembelajaran dipilih sesuai dengan tujuan pembelajaran, karakteristik siswa dan kebutuhan siswa". Untuk upaya yang dilakukan ialah memperbaiki tujuan pembelajaran agar sesuai dengan materi yang akan diajarkan dan menyesuaikan media pembelajaran dengan karakteristik siswa sehingga siswa dapat memahami materi dengan mudah. Hal ini dijelaskan Susanto (2016) "media pembelajaran dapat menumbuhkan motivasi belajar siswa menghindari kebosanan serta dapat mengkomunikasikan pesan-pesan kepada siswa, maka melalui media dapat mempermudah siswa dalam memahami materi-materi yang diberikan guru".

Berdasarkan analisis data pada lembaran pengamatan Rencana Pelaksanaan Pembelajaran (RPP) pada siklus 1 pertemuan 1 menunjukkan bahwa skor yang diperoleh adalah 72,2\% dengan kualifikasi cukup. Selanjutnya analisis data pada lembaran pengamatan Rencana Pelaksanaan Pembelajaran (RPP) pada siklus 1 pertemuan 2 menunjukkan bahwa skor yang diperoleh adalah 83,3\% dengan kualifikasi cukup. Pada siklus 1 ini diperoleh rata-rata 80,05\% pada hasil penilaian RPP dengan kualifikasi cukup (C). Berdasarkan data yang telah didapat bahwa Rencana Pelaksanaan Pembelajaran (RPP) siklus 1 pertemuan 1 dan pertemuan 2 telah mengalami peningkatan.

Pada kegiatan awal dalam mengkondisikan kelas, guru memberi semangat/motivasi pada siswa dan guru lupa untuk menyampaikan tujuan pembelajaran. Hal ini dikarenakan guru tergesa-gesa untuk mengajar sehingga melupakan hal yang penting untuk disampaikan.

Pada kegiatan inti dimana guru membagi siswa ke dalam beberapa kelompok untu mendiskusikan suatu materi, tetapi peserta didik malah meribut sehingga guru membagikan LKPD kepada siswa untuk dikerjakan agar keributan dapat dihentikan dan siswa dapat bertukar pikiran. Menurut Trianto (2011) "guru mendorong pertukaran ide gagasan secara bebas dan memberikan bantuan yang dibutuhkan siswa tanpa mengganggu aktivitas siswa". 
Pada langkah kesimpulan dimana guru mendapatkan tidak semua siswa menyimpulkan pembelajaran, sehingga mereka tidak semuanya memahami secara ringkas apa yang dipelajarinya.

Berdasarkan data yang diperoleh pada penilaian proses dan hasil belajar siswa pada pembelajaran tematik terpadu menggunakan model Quantum Teaching pada siklus I pertemuan 1belum mencapai nilai ketuntasan belajar yang ditetapkan memperoleh nilai ratarata 65,8 dan pada siklus I pertemuan 2 memperoleh rata-rata 80. Hal ini menunjukkan bahwa siklus Ihasil belajar siswa mengalami peningkatan. Menurut Mulyasa (2014) menyatakan bahawa "Pembelajaran dikatakan berhasil dan berkualitas apabila seluruhnya atau setidaknya sebagian besar $80 \%$ peserta didik terlibat secara aktif, baik fisik, mental, maupun sosial dalam proses pembelajaran, di samping menunjukan kegairahan belajar yang tinggi, semangat belajar yang besar, dan rasa percaya diri sendiri”.

\section{Siklus II}

Pelaksanaan pembelajaran pada siklus II tidak jauh berbeda dengan siklus I. Berdasarkan hasil pengamatan perencanaan pembelajaran pada siklus II mendapatkan kualifikasi sangat baik karena hampir semua aspek dapat terlaksana dengan baik sehingga mengalami peningkatan seperti pada aspek alokasi waktu sudah sesuai dengan waktu yang telah ditentukan, pada pemilihan materi ajar sudah sesuai dengan tujuan pembelajaran dan karakteristik siswa, pada aspek metode sudah sesuai dengan karakteristik siswa. Hasil pengamatan pada Rencana Pelaksanaan Pembelajaran (RPP) siklus II diperoleh 97,22\% dengan kualifikasi sangat baik (SB).

Berdasarkan pemaparan data diatas, dapat disimpulkan bahwa perencanaan pembelajaran tematik terpadu dengan menggunakan model Quantum Teaching telah terlaksana dengan kualifikasi sangat baik (SB) walaupun masih ada yang belum terlaksana. Sejalan dengan pendapat Masnur (dalam Reinita, 2017) menyatakan bahwa "RPP is teha design of lesson learning per unit that will be applied to teachers in learning in the classroom".

Berdasarkan perencanaan yang telah disusun sebelumnya, pelaksanaan pembelajaran dilakukan sesuai dengan apa yang telah direncanakan yang disajikan dalam 1x pertemuan. Pelaksanaan pembelajaran sudah dilaksanakan dengan baik, dimana guru sudah mengawali pembelajaran dengan mengkondisikan kelas beserta siswa, membaca doa, menyampaikan apersepsi, dan membangkitkan skemata siswa. Walaupun pada siklus II ini masih ada beberapa kekurangan.

Berdasarkan hasil pengamatan penelitian pada siklus II dapat dilihat dari hasil penilaian aspek guru adalah 94,44\% dan pada aspek siswa 94,444\% keduanya memperoleh kualifikasi sangat baik. Dapat disimpulkan bahwa pelaksanaan pembelajaran dengan menggunakan model Quantum Teaching siklus II sudah terlaksana sesuai dengan yang diharapkan.

Berdasarkan data yang diperoleh pada penilaian proses dan hasil belajar siswa pada pembelajaran tematik terpadu menggunakan model Quantum Teaching pada siklus II sudah 
mencapai nilai ketuntasan belajar yang ditetapkan memperoleh nilai rata-rata 94 . Hal ini menunjukkan bahwa siklus II sudah mencapai ketuntasan belajar. Menurut Mulyasa (2014) menyatakan bahawa "Pembelajaran dikatakan berhasil dan berkualitas apabila seluruhnya atau setidaknya sebagian besar $80 \%$ peserta didik terlibat secara aktif, baik fisik, mental, maupun sosial dalam proses pembelajaran, di samping menunjukan kegairahan belajar yang tinggi, semangat belajar yang besar, dan rasa percaya diri sendiri”.

\section{SIMPULAN}

Berdasarkan hasil penelitian dan pembahasan peneliti dapat disimpulkan bahwa proses pembelajaran dengan menggunakan model Quantum Teaching dapat meningkatkan proses dan hasil belajar siswa dan pembelajaran jadi lebih bermakna.

\section{DAFTAR RUJUKAN}

Khair. (2018). Pembelajaran B.Indonesia dan sastra di SD dan MI. Jurnal Pendidikan Dasar. XVII(2).

Mulyasa. (2014). Pengembangan dan Implementasi Kurikulum 2013. Bandung : PT Remaja Rosdakarya.

Majid, A. (2014). Pembelajaran Tematik Terpadu. Bandung : PT Remaja Rosdakarya.

Reinita. (2012). Peningkatan Proses Pembelajaran PKN Melalui Penggunaan Pendekatan Pembelajaran Nilai. Jurnal Ilmiah Ilmu Pendidikan. VXII(1) .(http://pedagogi.ppj.unp.ac.id/index.php/pedagogi.article/view/149).

Reinita. (2013). Model Listening Team. Jurnal Ilmiah Ilmu Pendidikan. XIII(1) (http://pedagogi.ppj.unp.ac.id).

Reinita. (2017). Pelatihan pendekatan value clarification technique model matriks dalam pembelajaran pkn-ips bagi guru. Jurnal Ilmiah Ilmu Pendidikan. XII(1). (http://pedagogi.ppj.unp.ac.id).

Reinita. (2017). The Improvement Application Value Of Cultural Character Nation To Students In Civil Learning With Value Clarification Technique Approach List Model In Class IV B SDN 16 Tarok Dipo Bukittinggi. ICSET. 118 (http://www.atlantis.pres.com/propceding/icset/17/25886593)

Susanto, A. (2016). Teori Pembelajaran di Sekolah Dasar. Jakarta : Prenada Media Group.

Trianto. (2011). Mendesain Model Pembelajaran Inovatif-Progresif. Jakarta : Prenada Media Group 